\title{
Role of epidermal growth factor and transforming growth factor $\alpha$ in the developing stomach
}

E J Kelly, S J Newell, K G Brownlee, S M Farmery, C Cullinane, W A Reid, P Jackson, S F Gray, J N Primrose, M Lagopoulos

\begin{abstract}
Aims-To determine whether epidermal growth factor (EGF) or the related transforming growth factor $\alpha$ (TGF $\alpha)$ may have a role in the developing human stomach; to substantiate the presence of EGF in human liquor in the non-stressed infant and whether EGF in amniotic fluid is maternally or fetally derived.
\end{abstract}

Methods-The temporal expression and localisation of EGF, TGFa, and their receptors during fetal and neonatal life were examined in 20 fetal and five infant stomachs. Simultaneously, samples of amniotic fluid and fetal urine from 10 newborn infants were collected and assayed for EGF by radioimmunoassay.

Results-EGF immunoreactivity was not noted in any of the specimens examined. In contrast, $\mathbf{T G F} \alpha$ immunoreactivity was shown in mucous cells from 18 weeks of gestation onwards. EGF receptor immunoreactivity was seen on superficial mucous cells in gastric mucosa from 18 weeks of gestation onwards. The median concentration of EGF was 30 and $8.5 \mathrm{pg} / \mathrm{ml}$ in amniotic fluid and fetal urine, respectively, suggesting that EGF is not produced by the fetus.

Conclusions-This study adds weight to the hypothesis that swallowed EGF, probably produced by the amniotic membranes, and locally produced TGF $\alpha$, may have a role in the growth and maturation of the human stomach.

(Arch Dis Child 1997;76:F158-F162)

Keywords: epidermal growth factor; transforming growth factor $\alpha$; EGF receptors; stomach

Department of

Surgery

S M Farmery

J N Primrose

Department of Pathology

C Cullinane

Institute of Pathology, University of Leeds

P Jackson

W A Reid

S F Gray

Institute of Anatomy

M Lagopoulos

Correspondence to:

Dr E J Kelly,

Neonatal Unit,

St James's University

Hospital,

Beckett Street,

Leeds LS9 7TF.

Accepted 11 December 1996
Experimental evidence supports a role for EGF on gut maturation, because EGF leads to increased growth of the gastric mucosa in neonatal rats, but not to functional maturation. ${ }^{78}$ Anti-EGF antiserum retards the growth of the gastrointestinal tract in newborn mice. ${ }^{9} \mathrm{EGF}$ given to adult rats following excision of their salivary glands protects against stress ulceration, presumably either by decreasing acid secretion or by increasing production of cytoprotective factors $^{10}$ through polyamine synthesis. ${ }^{11}$

In humans, Walker-Smith et al have reported that the use of EGF in the treatment of children with congenital microvillus atrophy increases small intestinal cell proliferation. ${ }^{12}$ In adults EGF expression and its receptor have been demonstrated in many cancers, ${ }^{13}{ }^{14}$ and in the stomach EGF has also been shown to be produced by a novel cell lineage following ulceration, where it may have a cytoprotective and growth promoting role. ${ }^{15}$

Beauchamp and colleagues detected expression of TGF $\alpha$ messenger RNA (mRNA) in guinea pig gastric mucosa and speculate that it has a regulatory role in both acid secretion and mucosal renewal, but they were unable to determine which specific cells express TGF $\alpha .{ }^{16}$ More recently, TGF $\alpha$ has been shown to be present in large quantities in the stomachs of adults with Ménétrier's disease, which is characterised by hypoproteinemia, hypochlorhydria, and increased mucus production. ${ }^{17}$ In this study TGF $\alpha$ production was localised to parietal cells in normal stomachs and in patients with Ménétrier's disease there was overexpression of TGF $\alpha$ in mucous cells where it may have a paracrine action to inhibit acid secretion. TGF $\alpha$ immunoreactivity has also been noted in biopsy specimens from adults with gastritis, the activity being strongest in areas of mucosa showing regenerative epithelial changes ${ }^{18}$; these cells also stain strongly for proliferating cell nuclear antigen (PCNA) which recognises cells in the G2 phase of the cell cycle. ${ }^{19}$

If $\mathrm{EGF}$ or TGF $\alpha$ have a role in the development of the human stomach then specific receptors present in the gastric mucosa and the timing of their appearance may correlate with other markers of gastric maturation. ${ }^{20}$ These growth factors may be produced locally, acting in an autocrine or paracrine manner, or may be swallowed. We therefore examined both fetal and infant stomachs for the presence of EGF, TGF $\alpha$, and EGF receptors, using immunohistochemical techniques. 
Table 1 Gestation of fetuses, and age of infants studied

\begin{tabular}{ll}
\hline & $\begin{array}{l}\text { No of } \\
\text { specimens }\end{array}$ \\
\hline Gestation (weeks): & \\
12 & 1 \\
13 & 1 \\
14 & 1 \\
15 & 1 \\
16 & 1 \\
18 & 2 \\
19 & 4 \\
20 & 3 \\
21 & 2 \\
24 & 1 \\
26 & 1 \\
34 & 1 \\
36 & 1 \\
Postnatal age & \\
(weeks): & \\
2 & 1 \\
4 & 1 \\
10 & 1 \\
13 & 1 \\
21 & 1 \\
\hline
\end{tabular}

Table 2 Birthweight $(\mathrm{kg})$ and sex of infants studied

\begin{tabular}{|c|c|c|}
\hline Infant & Sex & $\begin{array}{l}\text { Birthweight } \\
(\mathrm{kg})\end{array}$ \\
\hline 1 & Male & 2.97 \\
\hline 2 & Female & 3.23 \\
\hline 3 & Male & 2.96 \\
\hline 4 & Male & 3.40 \\
\hline 5 & Female & 3.37 \\
\hline 6 & Female & 2.91 \\
\hline 7 & Male & 3.65 \\
\hline 8 & Female & 3.15 \\
\hline 9 & Female & 3.04 \\
\hline 10 & Female & 3.71 \\
\hline
\end{tabular}

Fetal and neonatal life is a time of rapid growth and maturation of the gastrointestinal tract, and there is circumstantial evidence that these growth factors are important in human beings. High concentrations of EGF are seen in amniotic fluid and breast milk, ${ }^{21}$ suggesting that swallowed EGF may be important. Amniotic fluid is swallowed by the term fetus from 16 weeks' gestation, increasing to between $300-500 \mathrm{ml}$ of amniotic fluid per day at term. ${ }^{22}$ In the rabbit ligation of the oesophagus results in diminished gastric growth and secretory function, an effect that can be reversed by the infusion of amniotic fluid or EGF. ${ }^{23}$ Such direct evidence does not exist in humans, although in oesophageal atresia without fistula the stomach is small. In human amniotic fluid the EGF concentration greatly increases during the second trimester ${ }^{24}$ and concentrations are decreased in intrauterine growth retardation. ${ }^{25}$ The site of production is not known, but possible contenders include the amniotic membranes and the fetal kidney. ${ }^{26}{ }^{27}$ The concentrations of EGF in both venous and arterial cord blood have also been compared and no difference was noted between them, implying that the fetus does not receive EGF from the maternal circulation. ${ }^{26}$

We wished, therefore, to determine the concentrations of EGF in the amniotic fluid in the unstressed infant by determining the concentration of EGF in simultaneously collected samples of amniotic fluid and fetal urine, and to shed some light on the possible source of EGF production.

\section{Methods}

Twenty fetal and five infant stomachs were obtained from the University departments of pathology and obstetrics and gynaecology, St James's University Hospital, Leeds. The specimens resulted from therapeutic abortions, miscarriages, and cot deaths. The ages of the specimens are listed in table 1 . The maturity of fetuses is given in weeks of gestation, established from the last menstrual period and confirmed by antenatal ultrasound assessment and fetal foot length measurements. Infants who were studied following unexplained sudden infant death were all born at term and ages given are weeks of postnatal life. None of the infants had any known gastrointestinal disorder.

After fixation in formalin the specimens underwent standard histological processing. Immunohistochemical staining was carried out as follows: dewaxed $4 \mu \mathrm{m}$ sections were taken down to water and incubated in trypsin for 10 minutes. EGF receptor and TGF $\alpha$ activity were mapped using murine monoclonal antibodies (Sigma, Poole, UK and Oncogene Science, Cambridge, UK, respectively) and EGF activity was mapped using a polyclonal antibody to EGF, which is known to cross react with human EGF (Sigma). Initial antibody dilutions were 1 in 100,1 in 100 , and 1 in 10 , respectively. These were visualised using a biotin labelled secondary antibody and streptavidin/biotin horseradish peroxidase complex using the Vector elite ABC system
(Vector Labs, Peterborough, UK). The sections were stained with 3,3 diaminobenzidine and counterstained with haematoxylin. Suitable negative and positive controls were included.

All sections were viewed under a Leitz Dialux 20 EB microscope using $\times 50$ and $\times 100$ objectives by two independent, blinded, observers. This permitted mapping of the mucosal location of cells which contained EGF or $\mathrm{TGF} \alpha$ or had specific EGF receptors.

At term amniotic fluid is largely composed of fetal urine and secretions from the amniotic membrane. Immediately after delivery infants pass urine which has been produced in utero and this was used for analysis. Simultaneously collected samples of amniotic fluid and the first urine passed were collected from 10 term infants delivered at St James's University Hospital by elective caesarean section for maternal indications. The sex and birthweight of the infants are shown in table 2 .

The fluid samples were immediately placed on ice and centrifuged at $10000 \times g$ for 20 minutes. The supernatant fluid was collected and stored at $-20^{\circ} \mathrm{C}$ until assayed. EGF is stable at this temperature (Sigma, personal communication).

The concentration of EGF in amniotic fluid and urine was determined by radioimmunoassay using the hEGF pack (Amersham, UK) according to the manufacturer's instructions. Briefly, undiluted samples were incubated for 3 hours at room temperature in the presence of tracer ((3-[125I]iodotyrosyl) EGF (human recombinant), $20000 \mathrm{dpm}$ ), antiserum (rabbit anti-human EGF, final dilution 1 in 20000 ) and buffer in a final volume of 400 1. The magnetic Amerlex-M donkey anti-rabbit second antibody reagent was used for phase separation. Bound radioactivity was determined by gamma scintillation counting, and concentrations determined from a standard curve generated using human recombinant EGF (Sigma). All samples were assayed in triplicate. The radioimmunoassay is specific for human EGF and shows no cross reactivity with TGF $\alpha$.

Ethical approval for this study was obtained from the local research (ethics) committee and written consent was obtained from the parents of the term infants studied.

\section{Results}

IMMUNOHISTOCHEMISTRY

$E G F$

EGF activity was not detected in any of the fetal or infant stomachs examined. Its presence, using this technique, was noted in all of the positive controls from human salivary glands.

\section{$T G F a$}

The presence of TGF $\alpha$ immunoreactivity was noted in fetal stomachs from 18 weeks of gestation onwards. None was detected in the specimens dated at $12,13,14,15$ and 16 weeks of gestation. Mucous cells in the upper half of the gastric glands stained strongly positive, 


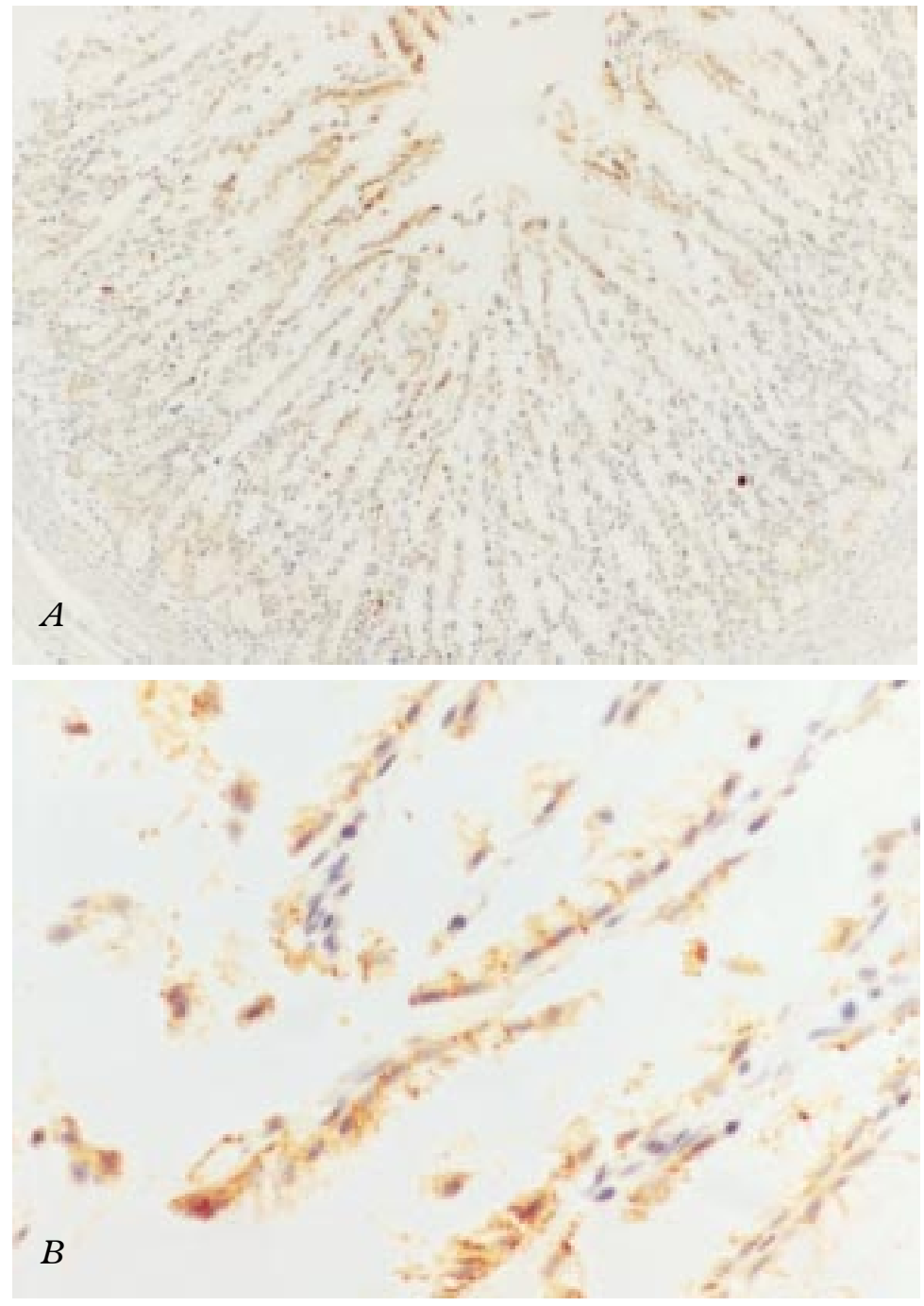

Figure 1 TGF a immunoreactivity in a fetal stomach at 18 weeks of gestation. (Counterstained with haematoxylin; original magnification $\times 440(A), \times 800$ (B).

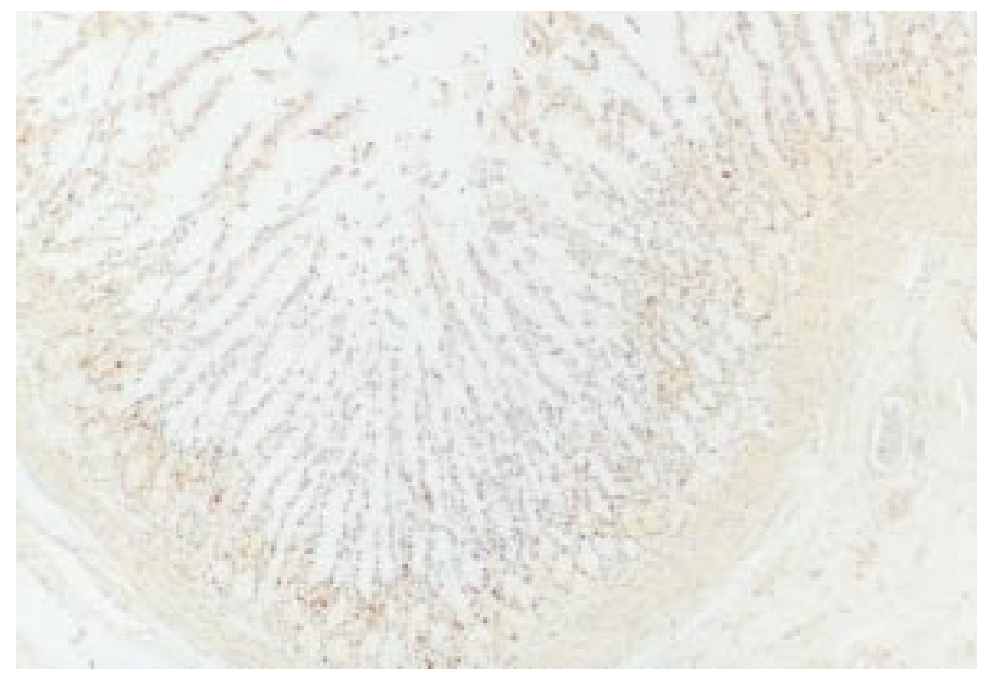

Figure 2 Location of EGF receptor activity in the same stomach. (Counterstained with haematoxylin, origninal magnification $\times 300$.)

with the immunoreactivity being localised to vesicles in the cytoplasm (figs $1 \mathrm{~A}$ and $\mathrm{B}$ ). About $60 \%$ of the mucous cells in this area stained positive for $\mathrm{TGF} \alpha$.

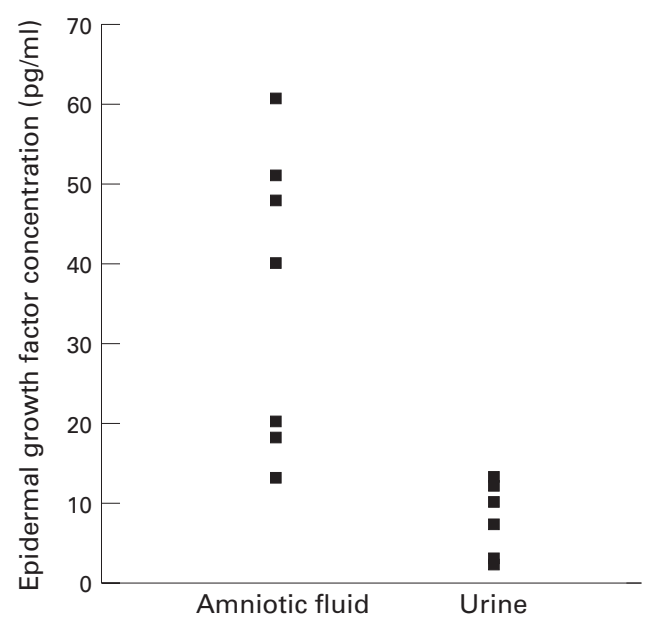

Figure 3 Concentration of EGF ( $\mathrm{pg} / \mathrm{ml}$ ) in cord liquor and fetal urine for 10 infants studied. Concentration in amniotic fluid is greater than that in urine $(P<0.001)$.

\section{$E G F / T G F$ a receptors}

EGF receptors were also detected in all of the stomachs studied from 18 weeks of gestation onwards. The EGF receptors were localised in the mucous cells and a small number of parietal cells. The mucous cells that showed EGF receptor immunoreactivity were found entirely at the base of the glands. About $85 \%$ of mucous cells in this area of the gland stained very strongly positive for EGF receptors (fig 2). Qualitatively, there was a higher density of EGF receptors in the antrum than in the body of the stomach. The receptors' location on the luminal aspect of the gastric mucosa allows them to be exposed to gastric contents.

None of the negative controls showed any staining following the application of 3,3 diaminobenzidine.

\section{RADIOIMMUNOASSAY}

The concentrations of EGF ( $\mathrm{pg} / \mathrm{ml}$ ) for fetal urine and amniotic fluid for each infant are shown in fig 3. The median concentration in amniotic fluid $(30(10-65) \mathrm{pg} / \mathrm{ml})$ was greater than that in fetal urine $(8.5(2-20) \mathrm{pg} / \mathrm{ml})$ $(\mathrm{P}<0.001$, Mann-Whitney U test). In no infant did EGF concentrations in urine exceed that found in amniotic fluid.

\section{Discussion}

We have conclusively shown that EGF receptors are present in fetal and infant stomachs from 18 weeks of gestation onwards and are located in mucous cells in the base of the gastric glands. This is in contrast to EGF itself which was not detected in any of the stomachs examined. However, TGF $\alpha$ was found in the superficial mucous cells, suggesting a possible paracrine role for this peptide, from 18 weeks of gestation. We also determined the concentration of EGF in 10 matched samples of amniotic fluid, fetal urine, and cord serum. The concentration of $\mathrm{EGF}$ in amniotic fluid was about four times higher that found in fetal urine.

EGF has been implicated in the maturation of many organ systems in a variety of experimental animals. ${ }^{3}$ Its role in the maturation of the gastrointestinal tract of rodents has 
been clearly documented. ${ }^{7-10}$ It seems likely, therefore, that EGF does have a role in the developing human stomach. We were unable to detect EGF in the fetal or infant stomach suggesting that it is not locally produced but swallowed EGF that may bind to the receptor. Alternatively, this may indicate that our method is not sensitive enough to detect its presence, or that it is intermittently produced in small amounts and rapidly secreted by the cell. Future work examining the production of EGF mRNA using rapidly expanding molecular techniques may answer this question.

$\mathrm{TGF} \alpha$ is being produced by superficial mucous cells in the developing stomach from 18 weeks of gestation onwards. This contrasts with normal adult gastric mucosa, where it is located in parietal cells. ${ }^{17}$ Its role in the developing stomach is unclear, but it may help to regulate mucosal growth. ${ }^{16}$ Its location in vesicles in luminally placed cells may allow it to be secreted into the stomach and it could have an action lower down the gastrointestinal tract, or it may act locally on the more deeply placed mucous cells.

The EGF receptor was located on the mucous cells located at the base of the gastric glands and in a small number of parietal cells. It was present from 18 weeks of gestation, at a time when the fetus is swallowing amniotic fluid containing high concentrations of EGF and when adjacent cells are producing TGF $\alpha$. This is a time when both chief cells ${ }^{28}$ and $G$ cells $^{29}$ first appear in the stomach, parietal cells are present in a functionally mature form, ${ }^{29}$ and when, macroscopically, the stomach is almost structurally mature..$^{30}$ As the fetus continues to swallow large amounts of amniotic fluid, EGF may act as a lumone, binding to its receptor. The origin of the EGF in amniotic fluid is unclear. Amniotic fluid is composed of both fetal urine and secretions from the amniotic membranes. EGF could be produced by the amniotic membranes or by the fetal kidney. We have shown that fetal urine contains about $25 \%$ of the concentration of EGF in amniotic fluid. Recently, amniotic membranes from healthy term infants have been shown to contain around $600000 \mathrm{pg}$ of EGF per gram of tissue. ${ }^{26}$ This is far greater than the amounts we found in amniotic fluid. These data suggest that the EGF in amniotic fluid is secreted by amniotic membranes rather than the fetal kidneys.

The role of EGF and TGF $\alpha$ in the developing stomach is not known. EGF is available to the fetus in amniotic fluid and to the newborn infant in breast milk, in large amounts. It is not denatured by gastric acid, ${ }^{31}$ allowing it to bind to receptors in the stomach, and it is absorbed intact from the immature gut. ${ }^{32}$ We have already documented that the developing human stomach has the functional capacity to produce gastric acid from the end of the first trimester ${ }^{29}$ and that even the most immature infant can produce and maintain a gastric $\mathrm{pH}$ of below $4 .^{33}$ If, however, gastric acid is not being produced in utero then a factor such as $\mathrm{EGF}$ or $\mathrm{TGF} \alpha$, which hinder gastric acid secretion, ${ }^{34}$ may be involved in mediating this achlorhydria in the fetus. At birth, when the large load of EGF present is removed the newborn infant is rapidly able to produce and maintain a low intragastric acidity.

The importance of EGF in the postnatal induction of gut maturity remains to be explored, but it is interesting to note that breast milk from mothers of preterm infants contains up to three times that of milk from mothers of term infants. ${ }^{35}$ This increase in EGF concentration is selective, with the total protein content of milk being similar in both groups.

This study has clearly shown that the developing stomach may be utilising luminally acting growth factors from at least 18 weeks of gestation onwards. These factors are produced both within the stomach and the amniotic membranes, and may increase gut growth and maintain a low level of gastric acid production.

We thank Cow and Gate Nutricia for funding this study.

1 Poulsen SS, Nexø E, Olsen PS, Hess J, Kirkegaard P. Immunohistochemical localisation of epidermal growth factor in rat and man. Histochemistry 1986;85:389-94.

2 Decker SJ. Epidermal growth factor and transforming growth factor-alpha induce differential processing of the Commun 1990;166:615-21.

3 Goodlad RA, Wilson TJG, Lenton W. Proliferative effects of urogastrone-EGF on the intestinal epithelium. Gut 1987;28:S137-43.

4 Sundell HW, Gray ME, Serenius FS, Escobedo MB, Stahlman MT. Effects of epidermal growth factor on lung
maturation in fetal lambs. Am $\mathcal{A}$ Pathol 1980;100:707-26.

5 Kasselberg AG, Orth DN, Gray ME, Stahlman MT. Immunocytochemical localisation of human epidermal growth factor/urogastrone in several human tissues. $f$ Histochem Cytochem 1985;33:315-22.

6 Kajikawa K, Yasui W, Sumiyoshi H, Yoshida K, Nakayama $\mathrm{H}$, Ayhan A. Expression of epidermal growth factor in human tissues. Immunohistochemical and biochemical analysis. Virchows Arch Pathol Anat 1991;418:27-32.

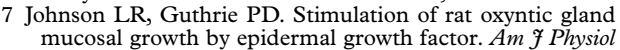
1987;238:G45-9.

8 Jansson T, Skarland H. Maternally administered epidermal growth factor stimulates fetal growth in the rat. Acta Physiol Scand 1990;138:245-6.

9 Zschiesche W. Retardation of growth and epithelial differentiation in suckling mice by anti- EGF antisera. Biomed Biochim Acta 1989;48:103-9.

10 Konturek SJ, Brzozowski T, Konturek PK, Majka J, Dembinski A. Role of salivary glands and epidermal growth factor (EGF) in gastric secretion and mucosal growth factor (EGF) in gastric secretion and mucosal integrity in rats

11 Brzozowski T, Majka J, Garlicki J, Drozdowicz D, Konturek SJ. Role of polyamines and prostaglandins in gastroprotective action of epidermal growth factor against ethanol injury. $\mathcal{F}$ Clin Gastroenterol 1991;31 (Suppl 1):S98-102.

2 Walker-Smith JA, Phillips AD, Walford N, Gregory $\mathrm{H}$, Fitzgerald JD, MacCullagh $\mathrm{K}$, et al. Intravenous epidermal growth factor/urogastrone increases small intestinal cell proliferation in congenital microvillous atrophy. Lancet 1985;ii: $1239-40$.

13 Toi M, Nakamura T, Mukaida H, Wada T, Osaki A, Yamada $\mathrm{H}$, et al. Relationship between epidermal growth factor receptor status and various prognostic factors in human receptor status and various pro

14 Gullick WJ. Prevalence of aberrant expression of the epidermal growth factor receptor in human cancers. Br Med Bull 1991;47:87-98.

15 Wright NA, Pike CM, Elia G. Ulceration induces a novel epidermal growth factor-secreting cell lineage in human gastrointestinal mucosa. Digestion 1990;46(Suppl 2):12533.

16 Beaumchamp RD, Barnard JA, McCutchen CM, Cherner JA, Coffey RJ. Localisation of transforming growth factor and its receptor in gastric mucosal cells. Implications for a regulatory role in acid secretion and mucosal renewal. $f$ Clin Invest 1989;84:1017-23.

17 Dempsey PJ, Goldenring JR, Soroka CJ, Modlin IM, McClure RW, Lind CD, et al. Possible role of transforming growth factor $\alpha$ in pathogenesis of Ménétrier's diseases: supportive evidence from humans and transgenic mice. Gastroenterology 1992;103:1950-63.

18 Bluth RF, Carpenter HA, Pittelkow MR, Page DP, Coffey RJ. Immunolocalisation of transforming growth factor $\alpha$ in normal and diseased human gastric mucosa. Gastroenterology 1993;104 (Suppl 4):A814.

19 Nagano K, Kawano S, Kobayashi I, Nakama A, Michida T, Masuda E, et al. Immunohistochemical localisation of TGF $\alpha$ and epidermal growth factor receptor in human stomach. Gastroenterology 1993;104 (Suppl 4):A637. 
20 Dial EJ, Lichtenberger LM. Development of the gastric barrier to acid. In:Lebenthal E, Human Gastrointestinal Devel-
opment. New York:Raven Press, 1989:353-63.

21 Shing YW, Klassbrun M. Human and bovine milk contain different sets of growth factors. Endocrinology 1984;115:273-82

22 Pritchard JA. Fetal swallowing and amniotic fluid volume. Obstet Gynecol 1966;28:606-10.

23 Mulvihill SJ, Stone MM, Fonkalsrud EW, Debas HT Trophic effect of amniotic fluid on fetal gastrointestinal development. I Surg Res 1986;40:291-6.

24 Watanabe $\mathrm{H}$. Epidermal growth factor in urine of pregnant women and in amniotic fluid throughout pregnancy. Gynecol Endocrinol 1990;4:43-50.

25 Shigeta K, Hiramatsu Y, Eguchi K, Sekiba K. Urinary and plasma epidermal growth factor levels are decreased in neonates with intrauterine growth retardation and in their mothers. Biol Neonate 1992;62:76-82.

26 Scott SM, Buenaflor GG, Orth DN. Immunoreactive human epidermal growth factor concentrations in amniotic fluid, umbilical artery and vein serum, and placenta in full-term umbilical artery and vein serum, and placenta in

27 Olsen PS, Nexø E, Poulsen SS, Hansen HF, Kirkegäärd P. Renal origin of rat epidermal growth factor. Regul Peptides
Ren 1985;10:767-71

28 Reid WA, McCechaen K, Branch T, Gray HDA, Thompson WD, Kay J. Immunolocalisation of aspartic proteinases in the developing human stomach. If Dev Physiol 1989; 11:299-303.

29 Kelly EJ, Lagopoulos M, Primrose JN. Immunocytochemical localisation of parietal cells and G-cells within the developing human stomach. Gut 1993;34:1057-9.

30 Kelly EJ, Newell SJ. Gastric ontogeny:clinical implications. Arch Dis Child 1994;71:F136-41.

31 Britton JR, George-Nascimento C, Udall JN, Koldovský O. Minimal hydrolysis of epidermal growth factor by gastric fluid of preterm infants. Gut 1989;30:327-32.

32 Gale SM, Read LC, George-Nascimento C, Wallace JC, Ballard FJ. Is dietary epidermal growth factor absorbed by premature human infants? Biol Neonate 1989;55:104-10.

33 Kelly EJ, Newell SJ, Brownlee KG, Primrose JN, Dear PRF. Gastric acid secretion in preterm infants. Earl Hum Dev 1993;35:215-20.

34 Gregory H, Bower JM, Willshire IR. Urogastrone and epidermal growth factor. In:Kastrup KW, Nielsen JH, eds. Growth Factors, 11th FEBS Meeting. Oxford:Pergamon, 1978:75-84.

35 Read LC, Ford WDA, Filsell OH, McNeil J, Ballard FJ. Is orally derived epidermal growth factor beneficial following premature birth or intestinal resection. Endocrinol Exp 1986;20:199-207. 